\title{
Seizure Induced by Extended-Release Bupropion Used for Smoking Cessation at Early Term and Therapeutic Dose
}

\section{Sigara Bırakmada Kullanılan Yavaş Salınımlı Bupropionun Erken Dönem ve Terapötik Dozda Neden Olduğu Nöbet}

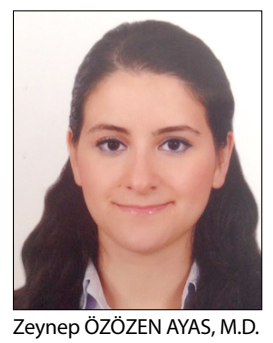

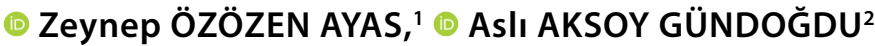

'Department of Neurology, Sakarya University Training and Research Hospital, Adapazarı, Turkey ${ }^{2}$ Department of Neurology, Namık Kemal University Faculty of Medicine, Tekirdağ, Turkey

\section{Summary}

Bupropion inhibits reuptakes of dopamine and noradrenaline. Since it is also a nicotine receptor antagonist, it acts as a drug used for smoking cessation. Bupropion is commonly preferred because of no side effects on weight, sexual function, and the lack of sedative effect. Immediate and sustained-release bupropion forms may trigger seizure activity. In the present article, we report a case of a 30-year-old man presenting with generalized tonic clonic seizures induced by extended-release bupropion. We also emphasized that extended-release bupropion, which is commonly used for smoking cessation therapy, may cause seizure at early term and therapeutic dose.

Key words: Extended-release bupropion; seizure; smoking cessation treatment.

\section{Özet}

Bupropion, dopamin ve noradrenalin geri alımlarını inhibe etmektedir. Aynı zamanda bir nikotin reseptör antagonisti olduğu için sigara bırakma için kullanılan bir ilaç olarak işlev görür. Bupropion kilo, cinsel fonksiyon üzerine yan etkisi olmaması ve sedatif etkisi olmamasından dolayı yaygın olarak tercih edilmektedir. Hızlı ve sürekli salınan bupropion formları nöbet aktivitesini tetikleyebilir. Bu yazıda, 30 yaşında erkek hastada yavaş salınımlı bupropiyonun neden olduğu jeneralize tonik klonik nöbet sunulmaktadır. Ayrıca sigarayı bırakma tedavisinde yaygın olarak kullanılan yavaş salınan bupropiyonun erken dönemde ve terapötik dozda nöbete neden olabileceğini vurguladık.

Anahtar sözcükler: Yavaş-salınımlı bupropion; nöbet; sigara bırakma tedavisi.

\section{Introduction}

Bupropion is commonly used both for depression and recently, for smoking cessation. It inhibits the reuptakes of dopamine, and noradrenalin; it also antagonizes acetylcholine in neuronal nicotinic receptors. ${ }^{[1]}$ Bupropion has three formulations on the basis of drug release kinetics. Immediate, sustained, and extended-release as a new form has been approved by Food and Drug Administration. In this article, we report a 30-year-old man who presented with generalized tonic clonic seizures that appeared six days after starting extended-release bupropion as part of smoking cessation therapy.

\section{Case Report}

A 30-year-old man presented to our hospital with generalized tonic clonic seizure activity. He had no history of epilepsy or any other systemic disease. Detailed medical profile indicated not any history of head trauma, febrile convulsions, or family history of epilepsy. He had a history of smoking for 10 years. Bupropion therapy was started for smoking cessation. 
He had taken bupropion $150 \mathrm{mg}$ for 4 days, after which the dose had been increased to $300 \mathrm{mg}$, and on that day he had seizure. His neurological examination was normal, and his vital signs were stable; he had normal hemogram, biochemistry blood tests and brain computerized tomography. Brain magnetic resonance imaging (MRI) and electroencephalography $(E E G)$ examination results were within normal limits. The patient was taken to follow-up; bupropion was stopped due to the possibility of inducing seizure. He had no recurrent seizures at the one-year follow-up period.

\section{Discussion}

Bupropion hydrochloride acts by inhibiting selective dopamine and noradrenalin reuptake. It is also a secondgeneration antidepressant that antagonizes nicotine receptors. It is considered to be beneficial in smoking cessation therapy as it increases dopamine concentration in nucleus accumbens. ${ }^{[2,3]}$ It is particularly popular compared with other antidepressants largely owing to the lack of sedative effect and adverse effects on sexual function. The most common side effects include dry mouth, nausea, agitation, and insomnia. ${ }^{[1]}$

It is believed that the immediate and sustained-release forms induce seizure activity more easily. Conversely, extended-release forms only rarely induce seizure. ${ }^{[4]}$ Seizures due to immediate-release bupropion were reported within the first six weeks of treatment. ${ }^{[5]}$ We think that our patient who had no predisposing factor for epilepsy and no abnormality in detailed tests, brain MRI, and EEG had seizure due to extended-release bupropion formulation. The patient had bupropion-induced seizure which did not include epilepsy criteria for diagnosis.

Tricyclic antidepressants and monoamine oxidase inhibitors, imipramine, amitriptyline are known to lower seizure threshold and increase seizure risk. A study reported that bupropion was the third-highest drug (9.49\%) to be associated with adverse drug reactions6. Bupropion can lower seizure threshold even at therapeutic doses of 150-450 mg/d. ${ }^{[1]}$ When immediate-release bupropion was administered at single doses greater than $150 \mathrm{mg}$ or at daily doses greater than $450 \mathrm{mg}$, seizures occured more commonly6. Reports exist mostly on seizure episodes due to bupropion overdose and intoxication. ${ }^{[7,8]}$ Our patient developed seizure activity at a therapeutic drug dose. The risk of having seizure due to bupropion depends on its dose. ${ }^{[9]}$
Similarly, our patient developed this complication after his dose had been increased to $300 \mathrm{mg} /$ day.

Two cases were reported that seizure due to extended-release bupropion at therapeutic doses. ${ }^{[4,10]}$ One of the patients experienced seizure at two months ${ }_{1}^{[4]}$ the other one at six months after beginning bupropion. ${ }^{[10]}$ Our patient experienced seizure on sixth days of bupropion administration. Seizure occurred at early term and in therapeutic dose, which suggests that extended-release bupropion form may be as risky as other formulations.

Bupropion also inhibits glutamate release in cerebrocortical nerve terminals in rats. A study reported that it possessed anti-seizure and anti-excitotoxic action through kainic acid. [11] These results surprisingly suggest that bupropion plays a role in the treatment of disorders characterized by seizure episodes and excitotoxicity. ${ }^{[11]}$

It must be remembered that extended-release bupropion, which is commonly used for smoking cessation can induce seizures in therapeutic doses and at early term.

\section{Informed Consent}

Written informed consent was obtained from the patient who participated in this study

\section{Peer-review}

Externally peer-reviewed.

\section{Conflict of interest}

The authors declare that they have no conflict of interest.

\section{Authorship Contributions}

Concept: Z.Ö.A, A.A.G.; Design: Z.Ö.A, A.A.G.; Materials: Z.Ö.A, A.A.G.; Data collection \&/or processing: Z.Ö.A, A.A.G.; Analysis and/or interpretation: Z.Ö.A, A.A.G.; Literature search: Z.Ö.A, A.A.G.; Writing: Z.Ö.A, A.A.G.; Critical review: Z.Ö.A, A.A.G.

\section{References}

1. Dwoskin LP, Rauhut AS, King-Pospisil KA, Bardo MT. Review of the pharmacology and clinical profile of bupropion, an antidepressant and tobacco use cessation agent. CNS Drug Rev 2006;12(3-4):178-207. [CrossRef]

2. Hurt RD, Sachs DP, Glover ED, Offord KP, Johnston JA, Dale LC, et al. A comparison of sustained-release bupropion and placebo for smoking cessation. N Eng J Med 1997;337(17):1195-202.

3. Johnston AJ, Ascher J, Leadbetter R, Schmith VD, Patel DK, Durcan $\mathrm{M}$, et al. Pharmacokinetic optimisation of sustained-release 
bupropion for smoking cessation. Drugs 2002;62:11-24.

4. Dedeoğlu E, Bayram B, Kızıler AU, Dedeoğlu B. Generalized tonic-clonic seizure induced by the extended- release bupropion hydrochloride formulation [Article in Turkish]. Bulletin of Clinical Psychopharmacology 2011;21(4):362-3. [CrossRef]

5. Alper K, Schwartz KA, Kolts RL, Khan A. Seizure incidence in psychopharmacological clinical trials: an analysis of Food and Drug Administration (FDA) summary basis of approval reports. Biol Psychiatry 2007;62(4):345-54. [CrossRef]

6. Heard K, Hurlbut KM. Bupropion. In: Dart RC, editor. The 5-Minute Toxicology Consult. Philadelphia, Pa: Lippincott Williams \& Wilkins; 2000. p. 278.

7. Noda $\mathrm{AH}$, Schu U, Maiere T, Knake S, Rosenow F. Epileptic seizure, coma and EEG burst-suppresion from suicidal bupropion intoxication. Epileptic Disord 2017;19(1):109-13.

8. Weerdenburg K, Finkelstein Y. A 12-year-old girl with seizures after intentional drug overdose. Bupropion overdose. Pediatr Emerg Care 2015;31(3):217-9. [CrossRef]

9. Johannessen Landmark C, Henning O, Johannessen SI. Proconvulsant effects of antidepressants-What is the current evidence? Epilepsy Behav 2016;61:287-91. [CrossRef]

10. Rissmiller DJ, Campo T. Extended-release bupropion induced grand mal seizures. J Am Osteopath Assoc 2007;107(10):441-2.

11. Lin KC, Wang CC, Wang SJ. Bupropion attenuates kainic acidinduced seizures and neuronal cell death in rat hippocampus. Prog Neuropsychopharmacol Biol Psychiatry 2013;45:207-14. 